\title{
Research On Electromagnetic Compatibility and Electronic Compatibility Standard of Instrument Control Equipment in Nuclear Power Plant
}

\author{
Min $\mathrm{Fu}^{1, \mathrm{a}}$, Jiurui $\mathrm{Li}^{1, \mathrm{~b}}$ and Xincai Chang ${ }^{1, \mathrm{c}}$ \\ ${ }^{1}$ China Nuclear Power Technology Research Institute Beijing Division \\ FL. $11^{\text {th }}$, CEC Building, No.6 south zhong guan cun St., Haidian District, Beijing, P.R.China \\ afu-min@cgnpc.com.cn, \\ blijiurui@cgnpc.com.cn , \\ cchangxincai@cgnpc.com.cn
}

\begin{abstract}
Keywords: instrument and control equipment, EMC susceptibility, EMC investigation.
Abstract. The method of using electromagnetic compatibility standard for nuclear power plant , and the electromagnetic compatibility and electromagnetic compatibility standard of instrument control equipment in nuclear power plant are put forward, by the research on electromagnetic compatibility of nuclear safety related equipment control equipment, and the investigation and summary of electromagnetic compatibility environment of nuclear power plants in foreign countries, and the research and summary of the use of electromagnetic compatibility standards in nuclear power plants in China.
\end{abstract}

\section{Introduction}

The anti-electromagnetic interference problem of the instrument control system in nuclear power station is generally considered as a qualitative analysis. But what is the impact on the quantity? Does it pose a threat to the operation and safety of nuclear power plants? How to identify and test the instrument control system which has been designed and manufactured? These problems are rarely seen in the earlier design of nuclear power plant instrument control system, it is particularly reflected in the electromagnetic compatibility standards for nuclear power plants.

\section{The necessity of Electromagnetic Compatibility Environment Study}

Many investigations are made on the electromagnetic compatibility in American Nuclear Plants by ORNL and EPRI. Based on the analysis and statistics of the events in the past decades caused by the control equipment, a few significant results are achieved[1,2,3 ]: "Between 1980 and 1991, 8\% of I\&C system failure related Jump heap and set up safety facilities (ESF) are caused by EMI/RFI[2], which are believed to be the dominant environment factor. Besides, according to the report LER between 1990 and 1993, 19\% events of digital I\&C equipment are caused by lightning stroke relevant EMI/RFI[3], and $67 \%$ of these events lead to Jump heap and disoperation by mistake eventually."

Breakdown of nuclear plants control equipment that are caused by EMI/RFI threatens the safe operation. However, the degree of the affection and the probability of leading to Shutdown and downtime events can only be analyzed based on the records of nuclear plants operation.

\section{Electromagnetic compatibility test research of overseas nuclear power plants}

MIL-STD-461 and -462 were originally promulgated in the late 1960s to control Electromagnetic Interference (EMI) emissions and susceptibility in U.S. military equipment.MIL-STD-46 1 provided test levels and MIL-STD-462 provided test methods. The radiated susceptibility tests were broken into a low frequency $(30 \mathrm{~Hz}-100 \mathrm{kHz})$ magnetic test (RSO1) and a higher frequency $(10 \mathrm{kHz}-40 \mathrm{GHz})$ electric field test (RS03). 
In 1991-92, data was collected at the Turkey Point and Zion nuclear plants. The data for Turkey Point comply with the SAMA Standard PMC 33.1-1978 [4]I guidance for susceptibility testing over the frequency range of $20-1,000 \mathrm{MHz}$ at levels of 3 and $10 \mathrm{~V} / \mathrm{m}$.

Turkey Point and Zion nuclear plants test process as shown in table 1

Table 1 Turkey Point and Zion nuclear plants EMC test and conclusion

\begin{tabular}{|c|c|c|c|}
\hline \multicolumn{4}{|c|}{ test conditions } \\
\hline test item & Zion nuclear plants & Turkey Point & conclusion \\
\hline $\begin{array}{l}\text { Conducted } \\
\text { Emissions }\end{array}$ & $\begin{array}{l}\text { there appears to be a } \\
\text { calibration error in the Zion data. } \\
\text { An abnormal } 20-\mathrm{dB} \text { gain } \\
\text { is indicated when data are } \\
\text { recorded in the range of } 30 \mathrm{~Hz} \text { to } \\
15 \mathrm{kHz} \text {, as compared to the } \\
\text { measurements } \\
\text { in the } 15-\mathrm{kHz} \text { to } 50-\mathrm{MHz} \\
\text { range. The Turkey Point data have } \\
\text { only a minor shift on similar } \\
\text { data plots-a difference that is } \\
\text { not fully explained. }\end{array}$ & $\begin{array}{l}\text { The spectral energy below } 5 \\
\mathrm{kHz} \text { was principally related to the } \\
\text { power frequency }(60 \mathrm{~Hz}) \text { and } \\
\text { harmonics, including suspected } \\
\text { switching EM } 1 \text { from inverters. } \\
\text { The } 60 \mathrm{~Hz} \text { current ranged from } \\
-100 \mathrm{~mA} \text { on the DC lines to }-18 \mathrm{~A} \\
\text { on the AC power cable } \\
\text { conductors. These signals fell off } \\
\text { at }-20 \mathrm{~dB} \text { per decade. } \\
\text { Above } 5 \mathrm{kHz} \text {, there were no } \\
\text { signals above } 3 \mathrm{~mA} \text {. Above } 15 \\
\mathrm{kHz} \text {, the data fell off at }-40 \mathrm{~dB} \text { per } \\
\text { decade. }\end{array}$ & $\begin{array}{l}\text { Both the AC and DC leads had } \\
\text { data taken from } 30 \mathrm{~Hz} \text { to } 50 \mathrm{MHz} \text { such } \\
\text { that the AC power current shows as an } \\
\text { emission when it should actually be } \\
\text { considered an operating } \\
\text { requirement.The conducted emissions } \\
\text { data obtained at Turkey Point and } \\
\text { Zion are comparable and well within } \\
\text { the low-frequency conducted } \\
\text { susceptibility limits defined in } \\
\text { MIL-STD-46 1E even though there } \\
\text { are multiple sources on the tested } \\
\text { power leads. The data are } 15-20 \mathrm{~dB} \\
\text { below recommended limits, assuming } \\
\text { a 50-ohm characteristic impedance. }\end{array}$ \\
\hline Electric Fields & $\begin{array}{l}\text { The highest radiated } \\
\text { narrow-band data measured at } \\
\text { Zion were } 104 \mathrm{dBpV} / \mathrm{m} \text {, or } 0.158 \\
\mathrm{~V} / \mathrm{m} \text {, at location } 1 \mathrm{CB} 50 \text {. This is } \\
\text { still } 36 \mathrm{~dB} \text { below the } 10 \mathrm{~V} / \mathrm{m} \text { level } \\
(140 \mathrm{dBpV} / \mathrm{m}) \text { normally used for } \\
\text { the susceptibility test, providing } \\
\text { adequate safety margin well above } \\
\text { the 6-dB safety margin. } \\
\text { This gives a } 30-\mathrm{dB} \text { measure } \\
\text { of uncertainty for variations } \\
\text { between power plants. In support } \\
\text { of this argument, revisions } \\
\text { incorporated into MIL-STD } 461 \mathrm{D} \\
\text { call for elimination of the } \\
\text { broad-band emission } \\
\text { measurements. }\end{array}$ & $\begin{array}{l}\text { The Turkey Point electric } \\
\text { field data are recorded only from } \\
20 \text { to } 1,000 \mathrm{MHz} \text {. The peak } \\
\text { narrowband } \\
\text { Turkey Point data are over } \\
100 \mathrm{dBpV} / \mathrm{m} \text { but } 40 \mathrm{~dB} \text { below the } \\
140 \mathrm{dBpV} / \mathrm{m}(10 \mathrm{~V} / \mathrm{m}) \text { test } \\
\text { level (except in the case of } \\
\text { deliberate keying of portable } \\
\text { transceivers, which can be } \\
\text { avoided administrative } \\
\text { through } \\
\text { controls). }\end{array}$ & $\begin{array}{l}\text { The radiated electric field } \\
\text { emissions recorded at the Zion plant } \\
\text { were very low, with the highest } \\
\text { measured field of } 0.16 \mathrm{~V} / \mathrm{m} \text {. The } \\
\text { radiated electric field data recorded at } \\
\text { both Turkey Point and } \\
\text { Zion correlated well where } \\
\text { comparisons could be made, with the } \\
\text { exception of intentional } \\
\text { transmitters at }-450 \mathrm{MHz} \text { (that is, } \\
\text { portable transceivers). }\end{array}$ \\
\hline $\begin{array}{l}\quad \text { Portable } \\
\text { Transceiver } \\
\text { Emissions }\end{array}$ & $\begin{array}{l}\text { Narrow-band measurements } \\
\text { as high as } 107.4 \mathrm{dBpV} / \mathrm{m} \text { were } \\
\text { recorded. Where transceiver } \\
\text { communications were observed } \\
\text { during mapping at Zion, the levels } \\
\text { were low: }-93 \mathrm{dBpV} / \mathrm{m} \text { at } 160 \\
\mathrm{MHz} \text { and }-87 \mathrm{dBpV} / \mathrm{m} \text { at } 450 \\
\mathrm{MHz} \text {. Short duration spikes } \\
\text { that relate to the intentional } \\
\text { transmitters, at } 0.022 \mathrm{~V} / \mathrm{m} \text {, are } \\
\text { well below test standard levels. } \\
\text { The steady-state EM1 level at } \\
\text { these frequencies was } 60 \mathrm{dBpV} / \mathrm{m} \\
\text { or below. }\end{array}$ & $\begin{array}{l}\text { The location of the portable } \\
\text { transceiver at Turkey Point was } \\
\text { not noted, and the narrowband } \\
\text { level was equal to or greater } \\
\text { than } 80 \mathrm{dBpV} / \mathrm{m} \text {.the intentional } \\
\text { transmitter levels at the } \\
\text { emergency bus load sequencer at } \\
\text { Turkey Point were recorded at } \\
133.5 \\
\mathrm{dBpV} / \mathrm{m} \text { (that is, }-5 \mathrm{~V} / \mathrm{m} \text { ) at } \\
450 \mathrm{MHz} \text {. }\end{array}$ & $\begin{array}{l}\text { Portable transceivers are a } \\
\text { known threat and the subject of NRC } \\
\text { Information Notice (IN) } 83-83 \\
\text { [ 141. Using the restricted operating } \\
\text { guidelines, the radiated } \\
\text { EM1 levels at the location of the } \\
\text { digital equipment can be maintained } \\
\text { well below a } 1 \mathrm{O}-\mathrm{V} / \mathrm{m} \\
\text { (140-dBpV/m) susceptibility test } \\
\text { level. Mapping does not appear to add } \\
\text { any useful information } \\
\text { for this known problem area. }\end{array}$ \\
\hline $\begin{array}{c}\text { Radiated } \\
\text { Magnetic Fields }\end{array}$ & $\begin{array}{l}\text { Radiated magnetic fields are a } \\
\text { as a radiated test in the MIL-STD, } \\
\text { inductive fields and should be perfor } \\
\text { were } 50 \mathrm{~cm} \text { ( } 20 \text { inches) from the sur } \\
\text { distance the highest measurement ( } \\
\text { The Zion data show that at } 50 \\
\text { the recorded levels were } 20-50 \mathrm{kH} \\
\text { MIL-STD-461E [4]. Being in the ne } \\
\text { from the source, that is, proportion } \\
\text { magnetic fields from the source, the } \\
\text { to digital } \\
\text { equipment. There were no sigI }\end{array}$ & $\begin{array}{l}\text { near-field and localized phenomenon } \\
\text { the MIL-STD-461C REO1 test is } \\
\text { med } 7 \mathrm{~cm} \text { from the surface of the dev } \\
\text { face and do not correlate directly witl } \\
\text { corresponding to 1CB76) is at least } \\
\mathrm{m} \text { ( } 20 \text { inches) from equipment, ther } \\
\mathrm{Iz}, 20 \mathrm{~dB} \text { below low-frequency rad } \\
\text { ar field, the level falls off as an inver } \\
\text { al to } 1 / \mathrm{R} 3 \text { or } 1 / \mathrm{R} 2 \text {, where } \mathrm{R} \text { is the } \\
\text { main concern is high current power } \\
\text { ificant levels found in the Zion data }\end{array}$ & $\begin{array}{l}\text { ecorded only at Zion. While described } \\
\text { tually a measurement of near-field or } \\
\text { e under test. The data obtained at Zion } \\
\text { any emissions criteria, although at this } \\
\text { dB below the MIL-STD- } 461 \text { limit. } \\
\text { were no field strengths of concern, and } \\
\text { ted susceptibility levels described in } \\
\text { cube or inverse square of the distance } \\
\text { stance. Because of the rapid decay of } \\
\text { equency conductors in close proximity } \\
50 \mathrm{~cm} \text { ( } 20 \text { inches). }\end{array}$ \\
\hline
\end{tabular}




\section{EMC standards of Nuclear power plants in China}

In this work, we collect the data sets related with EMI/RFI according to MIL-STDs that is defined by Department of Defense of United States. MIL-STD is used to define EMI/RFI environment, instead of the radiation data generated by the brand-new instruments. We summarize the usage according to the specific scenarios of nuclear plants in China, as shown in Table 2.

Table2 usage EMC standards of nuclear plants in China

\begin{tabular}{|l|l|}
\hline $\begin{array}{l}\text { EMI Standard used in } \\
\text { China }\end{array}$ & \multicolumn{1}{c|}{ Notes } \\
\hline RCC-E of France & $\begin{array}{l}\text { Qinshan Nuclear Power Plant Phase I uses the standard of U.S., and Phase II and Tian } \\
\text { Nuclear Power Plant are imported from Canada and Russia, thus following their standa } \\
\text { Dayawan and Lingao plants use the analog control system (Bailey 9020), and Lingao Pr } \\
\text { II uses the digital control system (Siemens Teleperm). These two systems are both } \\
\text { compatible with the RCC-E standard of France. }\end{array}$ \\
\hline GB/T11684 & $\begin{array}{l}\text { In 1989, Liberation army (PLA) chemical defense research institute drafted a national } \\
\text { standard GB/T11684 "Electromagnetic environment for nuclear instruments and the } \\
\text { experiments methods", according to the proposal of the committee of standardization } \\
\text { national nuclear instruments (Nuclear Industry System). In 2003, a major revision an } \\
\text { update is made on this standard, referring to GB/T17626 "Electromagnetic compatibil } \\
\text { experiments and measurement" (equivalent to IEC61000-4). }\end{array}$ \\
\hline GB/T17625 & $\begin{array}{l}\text { The electromagnetic compatibility problem has a national standard, composed of } \\
\text { GB/T17625 GB/T17626, GB/T17799, along with a few of standards on measurements } \\
\text { These are corresponding to the international standards IEC61000-3, IEC61000-4, } \\
\text { IEC61000-6, which are applicable in aviation, electronics, and electrical industry. }\end{array}$ \\
\hline
\end{tabular}

\section{The use of standard methods}

Nuclear I\&C equipment important to the safety of a nuclear plant shall satisfy the requirements for immunity to electromagnetic interference documented in this standard.

The establishment of immunity requirements shall address items a) to $n$ ), below. If an item is deemed to be inappropriate for the equipment under test, exemption shall be justified by consideration of operating conditions or other relevant factors. The immunity requirements shall address:

a) surge disturbances of large energy;

b) voltage dips, short interruptions, voltage variations;

c) electrical fast transients/bursts;

d) electrostatic discharges;

e) radio-frequency electromagnetic field, radiated;

f) power frequency magnetic field;

g) pulse magnetic field;

h) conducted disturbances, induced by radio-frequency field;

i) oscillatory damped disturbances;

j) fluctuations of power supply voltage;

k) conducted common mode disturbances in the range of $0 \mathrm{~Hz}$ to $150 \mathrm{~Hz}$;

1) variations of power frequency in supply systems;

m) harmonics and interharmonics distortion of power supply waveform;

n) damped oscillatory magnetic field.

Nuclear I\&C equipment supplied for use in systems important to safety may also be required to satisfy emission requirements. Depending on the installed location of nuclear I\&C equipment, and the severity of electromagnetic conditions during the operation, the following severity category on disturbance immunity of nuclear I\&C equipment should be established: I, II, III, and IV 
Table 3 - Classification of disturbance immunity

for nuclear I\&C equipment important to safety

\begin{tabular}{|l|c|c|c|c|}
\hline \multirow{2}{*}{} & \multicolumn{4}{|c|}{ Severity of electromagnetic environment of equipment location } \\
\cline { 2 - 5 } & Light EME & Middle EME & Harsh EME & Severe EME \\
\hline Immunity level & II & IV \\
\hline $\begin{array}{l}\text { NOTE Representative qualitative parameters for the classification of the severity of electromagnetic conditions in } \\
\text { location for the allocation of nuclear I\&C equipment are given for guidance in Annex B. }\end{array}$ \\
\hline
\end{tabular}

For each item of nuclear I\&C equipment, the immunity level shall be individually determined for each of the disturbance types (items a) to $n$ )).

A proper arrangement group on disturbance immunity may be determined for each nuclear I\&C equipment under tests according to Table 1 and in conformity with nuclear I\&C equipment destination and influence on safety as well as in conformity with class of severity of electromagnetic environment.

The parameters of the equipment evaluation test project is according to class of interference severity of nuclear equipment to determine 。

Functional quality criteria of nuclear I\&C equipment, according to the results of the test, under test for disturbance immunity aregiven in Table 4[5].

Table 4 - Functional quality criteria of nuclear

I\&C equipment under test for disturbance immunity

\begin{tabular}{|c|l|}
\hline $\begin{array}{c}\text { Functional quality criteria of nuclear } \\
\text { I\&C equipment under test for } \\
\text { disturbance immunity }\end{array}$ & \multicolumn{1}{c|}{$\begin{array}{c}\text { Operational quality of nuclear I\&C equipment during tests for } \\
\text { disturbance immunity }\end{array}$} \\
\hline A & $\begin{array}{l}\text { The apparatus shall continue to operate as intended. No degradation of } \\
\text { performance or loss of function is allowed below a performance level specified by } \\
\text { the manufacturer when the apparatus is used as intended.The performance level } \\
\text { may be replaced by a permissible loss of performance. If the minimum } \\
\text { performance level or the permissible performance loss is not specified by the } \\
\text { manufacturer, then either of these may be derived from the product description } \\
\text { and documentation and what the user may reasonably expect from the apparatus if } \\
\text { used as intended. }\end{array}$ \\
\hline B & $\begin{array}{l}\text { The apparatus shall continue to operate as intended after the test. No degradation } \\
\text { of performance or loss of function is allowed below a performance level specified } \\
\text { by the manufacturer when the apparatus is used as intended. The performance } \\
\text { level may be replaced by a permissible loss of performance. During the test } \\
\text { degradation of performance is allowed. If the minimum performance level or the } \\
\text { permissible performance loss is not specified by the manufacturer, then either of } \\
\text { these may be derived from the product description and documentation and what } \\
\text { the user may reasonably expect from the apparatus if used as intended. }\end{array}$ \\
\hline C & $\begin{array}{l}\text { Temporary loss of function is allowed, provided the function is self-recoverable or } \\
\text { can be restored by the operation of controls. }\end{array}$ \\
\hline
\end{tabular}

\section{Conclusions}

Electromagnetic Compatibility: the compatibility of nuclear instruments is getting more and more attention, which significantly affects the safe operation of nuclear plants.

I Compatible standard of nuclear instruments: it is crucial to select the applicable standard of electromagnetic compatibility. Different standards cannot be mixed. Once a standard is selected, it should be used through the project (exceptions are only allowed when certain items are not available).

I The recommended standard: based on the investigation and analysis, NRC RG1.180 or "evaluation rules for electromagnetic compatibility on safety related instruments" is recommended as the standard for evaluating the electromagnetic compatibility of nuclear instruments.

I Although there is no electromagnetic compatibility experiments conducted in China as in Jerusalem or Turkey, these experiments can be used as the reference when evaluating the experiments in China.

I The nuclear plants investigated in this work are all compatible with the MIL-STD-461C 
standard, which can be used to solve the problems in the experiments designed for evaluating the electromagnetic compatibility in China's nuclear plants.

I The analysis can be conducted based on the classifications of interference sources and formats of China's nuclear plants.

I The experiments referred in this work are conducted in the defined environment, from low frequency to high frequency, from conductance to irradiation, from magnetic field to electric field, from source of interference to sensitivity. The electromagnetic compatibility tests conducted in the future can follow the similar rules.

I There is still a huge gap between China and other developed countries, on the electromagnetic compatibility standard, research depth, evaluation coverage. For new power plants, it is necessary to design the electromagnetic environment according to the standard working conditions. For built plants, it is necessary to re-evaluate the electromagnetic compatibility, by referring to the experiments conducted in foreign countries, thus making sure the safe operating in different scenarios.

I For the distinctions of the nuclear power plants in China, specific conditions should be considered, while following the widely applicable rules and methods. At the same time, modifications and additions should be made to the currently adopted standards and regulations.

I It is recommended to use applicable shielding technics in the nuclear power plants, to prevent potential interference on the nuclear power plants.

\section{References}

[1] ORLN "Electromagnetic compatibility in nuclear power plants"

[2] NUREG/CR-5904, “"Finctional Issues and Environmental Qualification of Digital Protection Systems of Advanced Light-Water Nuclear Reactors" USNRC, April 1994

[3] NUREG/CR-6579, “"Digital I\&C Systems in Nuclear Power Plants: Risk-Screening of Environmental Stressors and a Comparison of Hardware Unavailability With an Existing Analog System," USNRC,January 1998.

[4] Electromagnetic Susceptibility of Process Control Instrumentation. Scientific Apparatus Makers Association (SAMA), Process Measurement Control, Inc. (PMC) Document 33.1,1978.

[5]Fumin , Kong Hanzhi,Qiu Jianwen. NB/T 20218-2013 Nuclear power plants - Instrumentation and control important to safety -Requirements for electromagnetic compatibility testing 